\title{
Repair of Spinal Cord Injury; Mesenchymal Stem Cells as an Alternative for Schwann Cells
}

\author{
Mehrdad Moosazadeh Moghaddam', Shahin Bonakdar², Mohammad Ali Shokrgozar ${ }^{2 *}$, Shahab Faghihi ${ }^{* *}$ \\ ${ }^{1}$ Stem Cell and Regenerative Medicine Group, National Institute of Genetic Engineering and Biotechnology (NIGEB), Tehran, Iran \\ ${ }^{2}$ National Cell Bank, Pasteur Institute of Iran, Tehran, Iran
}

Corresponding Authors: Shahab Faghihi, Associate Professor, Stem Cell and Regenerative Medicine Group, National Institute of Genetic Engineering and Biotechnology (NIGEB), Tehran 14965/161, Iran. Tel: +98-21-4478 7386, Fax: +98-21-4478 7386, Email: sfaghihi@nigeb.ac.ir

Mohammad Ali Shokrgozar, Professor, Pasteur Institute of Iran, Tehran 3159915111, Iran. Email: mashokrgozar@pasteur.ac.ir

Received March 2, 2018; Revised May 24, 2018; Accepted May 29, 2018; Online Published June 20, 2018

\begin{abstract}
Spinal cord injury $(\mathrm{SCl})$ is one of the most severe types of disabilities that has a limited capacity to repair; therefore, medical interventions are essential to the treatment of injuries. Cell transplantation is one of the remarkable strategies for the treatment of spinal cord injury. Transplantation of Schwann cells (SCs) has shown a great promising result for SCI but harvesting SC is limited due to donor complications and limited cell collection capacity. However, the use of stem cells to differentiate into SCs can reduce the risks associated with the use of mature cells in the grafting process. Mesenchymal stem cells can differentiate to various type cells. They are as easily accessed source with high growth rate and low immunogenicity; therefore, these properties make them an interesting source for cell therapy. These cells can be transdifferentiated into SC-like cells in neuronal induction media. Accordingly, many studies demonstrated that mesenchymal cells are well suited for cell therapy of SCl. This article briefly discusses the treatment of SCI by cell transplantation and the benefits of using Mesenchymal stem cells as an alternative for SCs. Keywords: Spinal Cord Injury, Cell Transplantation, Mesenchymal Stem Cell, Schwann Cell

Citation: Moosazadeh Moghaddam M, Bonakdar S, Shokrgozar MA, Faghihi S. Repair of spinal cord injury; mesenchymal stem cells as an alternative for Schwann cells. J Appl Biotechnol Rep. 2018;5(2):42-47. doi:10.29252/jabr.05.02.01.
\end{abstract}

\section{Introduction}

Spinal cord injury (SCI) is one of the most severe types of disabilities, which due to its negative impacts on motor control abilities, has a major impact on patient's life and causes the person to face a wide range of constraints. ${ }^{1,2}$ The statistics show that the incidence rates of developed countries ranged from 13 to 163 per million people while the rates of non-developed countries varied from 13 to 220 per million people. In addition, the prevalence of SCI is 490 to 526 per million population among developed countries and for nondeveloped countries, reported prevalence is about $440 .^{3}$ On the other hand, the cost of caring for a SCI is also huge. For example, the annual cost of spinal cord injuries is estimated to be more than $\$ 9$ billion in America and a tetraplegia patient will cost over 900000 in the first year and \$ 170000 over the next years. ${ }^{4}$ In Iran, there are more than 2000 SCI veterans due to Iraq-Iran war and more than 15000 cases of spinal cord injuries have been diagnosed until today. According to the studies, the most common causes of spinal cord injuries include injuries during driving and sports, violent acts and war injuries, falling from heights, some diseases, and medical incidents. Complications due to spinal cord injuries include loss of complete or partial movement ability (such as walking) and sensation in the affected area and the more upper body is engaged, the more will be the complications. ${ }^{5,6}$ However, injured spinal cord axons have the ability to restore themselves, but the maximum axon growth is about one millimeter, although this restoration process is not happening at a satisfactory level. On the other hand, the glial scars formation and the lack of growth stimulating symptoms such as semaphorin and ephrin and on the contrary the existence of inhibition signals like myelin sheath components (myelinassociated glycoprotein, Nogo-A) are regarded as inhibitory factors of axon growth. ${ }^{7}$ Therefore, considering the extent and intensity of the disabilities caused by spinal cord injuries and their increased incidence, numerous efforts have been made in order to elevate the effects of mentioned damages. The effective treatment of the injury depends on the type and severity of the damage, although the high costs of treatment can affect the process of healing. ${ }^{8,9}$ The use of cell therapy is one of the solutions that have been widely considered in the last 2 decades due to the high growth rate of regenerative medicine based on tissue engineering and stem cell. ${ }^{10,11}$

Cell Transplantation Therapy for Spinal Cord Injury

The utilization of cell therapy is one of the used strategies

Copyright (C) 2018 The Author(s). This is an open-access article distributed under the terms of the Creative Commons Attribution License (http:// creativecommons.org/licenses/by/4.0), which permits unrestricted use, distribution, and reproduction in any medium, provided the original work is properly cited. 
for treatment of SCI which includes embryonic tissue transplantation, use of Schwann mature cells, and embryonic, bone marrow, nervous stem cells, and olfactory ensheathing cells (OECs). ${ }^{11,12}$ In some cases gene therapy and insertion of genes such as NT-3, BDNF, NGF, which play an important role in restoring spinal cord injuries, into stem cells or mature cells such as fibroblasts is also used. ${ }^{13,14}$ Considering the progress in stem cells and restorative medicine, stem cell therapy compared to the use of mature cells is one of the most important and remarkable therapies for SCI or other injuries and diseases because of long-term self-renewal ability of stem cell and the possibility of genetic manipulation. ${ }^{15,16}$ However, access to an appropriate stem cell source is one of the most limitations and their differentiation into target cells is one of the key steps in using these cells for treatment purposes.

In general, the applied cell therapy techniques in order to repair SCI can be summarized in the following cases $^{17,18}$ :

- Transplantation of peripheral nerve

- Transplantation of Schwann cells (SCs)

- Transplantation of olfactory nervous system cells

- Transplantation of embryonic CNS tissue

- Transplantation of embryonic stem/progenitor cells

- Transplantation of adult stem/progenitor cells

- Transplantation of engineered stem/progenitor cells

- Transplantation of activated macrophages

In 1999, for the first time, German researchers by employing embryonic stem cells (ESCs) derived from glial precursors showed that a protective myelin sheath could be formed in the rat-damaged spinal cord. ${ }^{19}$ In addition, other studies showed that these cells could improve the rat's SCI at a very limited level. In 2000, for the first time, olfactory stem cells were used for repairing SCI in rats. ${ }^{20}$ Since then, many studies have reported the use of stem cells and tissue engineering to repair these injuries with different levels of recovery. ${ }^{21-26}$ Here is a variety of studies due to the complexity of the spinal cord tissue and the lack of complete recognition of the effective repair process at the clinical level. However, the use of SCs is one of the options that has been considered in recent years for the treatment and repair of spinal cord injuries due to the considerable potential of these cells including ${ }^{27-29}$ :

- Produce growth factors, which stimulate some nerve fiber (axon) regeneration

- Produce components of the extracellular matrix, which supports regenerating axons

- Surround and re-insulate (re-myelinate) axons that lost their insulation after injury

- Restore axonal communication upon re-myelination

- Spontaneously enter the spinal cord after SCI

Although, there are limitations for transplanted SCs such as (1) need to provide a neurotransmitter for extraction and transplantation of SCs, (2) the possibility of secondary damage during the isolation and receipt of primary SCs, (3) possibility of immunogenic responses, and (4) the need for long-term cell cultivation and proliferation processes. Accordingly, the use of stem cells to differentiate into SCs can reduce the risks associated with the use of mature cells in the grafting process.

Stem cells can be characterized based on their differentiation potential including totipotent, pluripotent, unipotent, and adult stem cells. Totipotent stem cells can form an entire embryo including the extraembryonic tissues. Pluripotent stem cells can trigger the three embryonic germ layers: mesoderm, endoderm, and ectoderm. Unipotent or progenitor stem cells can only differentiate into one defined cell type and adult stem cells are capable of multi-lineage differentiation in cells of only one germ layer. ${ }^{30,31}$ The differentiation potential of stem cells is related to their developmental stage so that the potential of differentiation decreases from an ESC to a specialized tissue stem cell. In addition, induced pluripotent stem cells (iPSC) as a type of pluripotent stem cell can be generated directly from adult cells. ${ }^{32-34}$

So far, many studies have been done on the use of stem cells to repair spinal cord injuries by differentiating stem cells into SC. In these studies, various types of stem cells have been evaluated based on development stage including tissue source and iPSC. Table 1 presents different sources of stem cells that have been evaluated for SCI. ${ }^{18}$

Mesenchymal Stem Cells as an Alternative for Schwann cell Transplantation

Bone marrow and adipose-derived stem cells (ADSCs) as mesenchymal stem cells (MSCs), which also derived from peripheral blood, placenta and umbilical cord, the lung, and the heart, are multipotent stromal cells that can differentiate to various type cells such as osteoblasts, chondrocytes, and adipocytes. They are as easily accessed source with high growth rate, low immunogenicity and a favorable ethical profile and better safety that can differentiate to all mesodermal lineage cells, therefore these properties make them an interesting source for cell therapy. ${ }^{35,36}$ MSCs can be transdifferentiated into SC-like cells in neuronal induction media. ${ }^{37,38}$ On the other hand, studies have shown that SCs that differentiated from MSCs enhance and support neurite outgrowth, axonal surviving and remyelination. ${ }^{39}$ In many studies, MSCs is considered as a brilliant cell for the treatment of central nervous system. ${ }^{40,41}$ In addition, transplantation of SCs derived from mesenchymal stem cells as a potentially useful treatment for SCI is also confirmed. ${ }^{42,43}$ Studies have shown that MSCs can produce various growth factors, neuroprotective cytokines and chemokines (Figure 1) such as vascular endothelial growth factor (VEGF), hepatocyte growth factor (HGF), fibroblast growth factor (FGF), nerve growth factor (NGF), and brain-derived neurotrophic factor (BDNF), which enhances functional benefits associated with MSC transplantation. ${ }^{42,44}$ Accordingly, MSCs are an efficient source of HGF suggested that the therapeutic effects of MSC transplantation are partly mediated by HGF secretion. This factor blocked secretion of transforming growth factor- $\beta$ (TGF- $\beta$ ) from activated astrocyte cells and prevented expression of specific chondroitin sulfate proteoglycan (CSPG) species. Studies demonstrated that transplantation of HGF-overexpressing MSCs significantly decreased expression of neurocan and glycosaminoglycan chain deposition around hemisection lesions in the spinal cord. ${ }^{42,45,46}$ Also in animal models, HGF-MSCs showed an increase in axonal growth and improvement in functional recovery, which confirms that HGF can act as an attractive signal for the guidance of axon 
Table 1. Comparison of Different Sources of Stem Cells Used for Peripheral Nerve Regeneration ${ }^{18}$

\begin{tabular}{|c|c|c|c|c|c|}
\hline Stem Cell & Classification & Advantage & Disadvantage & $\begin{array}{l}\text { Preclinical or } \\
\text { Clinical }\end{array}$ & Use Mechanism \\
\hline ESCs & $\begin{array}{l}\text { Pluripotent stem } \\
\text { cells }\end{array}$ & $\begin{array}{l}\text { Homogenous, no detrimental impact of age } \\
\text { and disease, unlimited cell number, better } \\
\text { differentiation potential, and longer lasting } \\
\text { proliferation capacity }\end{array}$ & Teratoma formation, ethical dilemma & Preclinical & $\begin{array}{l}\text { Myelination and/or } \\
\text { neurotrophic factors }\end{array}$ \\
\hline BMSCs & Multipotent cells & Easily accessible without ethical concerns & $\begin{array}{l}\text { Lower capacity of proliferation and } \\
\text { differentiation, invasive procedure for } \\
\text { autologous harvesting }\end{array}$ & Preclinical & $\begin{array}{l}\text { Myelination, neurotrophic } \\
\text { factors }\end{array}$ \\
\hline ADSCs & $\begin{array}{l}\text { Multipotent stem } \\
\text { cells }\end{array}$ & $\begin{array}{l}\text { Easy to harvest, higher proportion and } \\
\text { superior proliferation }\end{array}$ & $\begin{array}{l}\text { Differentiation potential towards } \\
\text { adipocytes }\end{array}$ & Preclinical & $\begin{array}{l}\text { Myelination, neurotrophic } \\
\text { factors, reduce inflammation }\end{array}$ \\
\hline NSCs & $\begin{array}{l}\text { Multipotent stem } \\
\text { cells }\end{array}$ & & Difficult to be harvested & Preclinical & Replace SCs \\
\hline $\begin{array}{l}\text { Fetal-derived } \\
\text { stem cell }\end{array}$ & $\begin{array}{l}\text { Multipotent stem } \\
\text { cells }\end{array}$ & Less immunoreactivity & Cell bank for storage & Preclinical & $\begin{array}{l}\text { Augmented blood perfusion } \\
\text { and enhanced intraneural } \\
\text { vascularity }\end{array}$ \\
\hline HFSCs & $\begin{array}{l}\text { Multipotent stem } \\
\text { cells }\end{array}$ & $\begin{array}{l}\text { Abundant and accessible source, } \\
\text { differentiate into pure human SC } \\
\text { population }\end{array}$ & Difficult to isolate & Preclinical & $\begin{array}{l}\text { Replace SC myelination, } \\
\text { neurotrophic factors }\end{array}$ \\
\hline DPSCs & $\begin{array}{l}\text { Multipotent stem } \\
\text { cells }\end{array}$ & $\begin{array}{l}\text { Stronger harvesting and proliferation } \\
\text { potential, as well as greater clonogenic } \\
\text { potential }\end{array}$ & Require storage & Preclinical & $\begin{array}{l}\text { Replace SC myelination, } \\
\text { neurotrophic factors }\end{array}$ \\
\hline SKP-SCs & Multipotent cells & Easy to harvest & Long time to differentiate & Preclinical & Replace SC myelination \\
\hline MDSPCs & Progenitor cells & Abundant and accessible source & Limited research & Preclinical & Neurotrophic factors \\
\hline iPSCs & $\begin{array}{l}\text { Pluripotent stem } \\
\text { cells }\end{array}$ & $\begin{array}{l}\text { Inducible from easily obtainable somatic } \\
\text { cells }\end{array}$ & $\begin{array}{l}\text { Subdued efficiency and enhanced } \\
\text { variability during the differentiation } \\
\text { process, epigenetic memory from the } \\
\text { original somatic cells, chromosomal } \\
\text { aberrations, stronger tumorigenicity }\end{array}$ & Preclinical & $\begin{array}{l}\text { Replace SC myelination, } \\
\text { neurotrophic factors }\end{array}$ \\
\hline
\end{tabular}

ESCs: embryonic stem cells; BMSCs: bone marrow-derived stem cells; ADSCs: adipose-derived stem cells; NSCs: neural stem cells; HFSCs: hair follicle stem cells; DPSCs: dental pulp stem cells; SKP-SCs: skin-derived precursor stem cells; MDSPCs: muscle-derived stem/progenitor cells; iPSCs: induced pluripotential stem cells; SC: Schwann cell.

motor to the target tissue. ${ }^{45}$ In addition to growth factors, immunological cytokines are also involved in the process of stem cell therapy after SCI. According to the studies, transplantation of MSCs into a lesion spinal cord leads to a reduction in Tumor necrosis factor alpha (TNFa), interleukin 1 beta (IL-1 $\beta$, IL-2), IL-4, IL-6, and IL-12 secretion. ${ }^{47,48}$ In addition, implantation of MSCs inhibits second-phase neuronal injury by suppressing lymphocyte and microglia effects and reduces the inflammatory reaction in the local environment after SCI. ${ }^{49}$ These results confirm that MSC administration can help to neuronal survival after lesion through cytokine release and immunomodulation. It has also been demonstrated that apoptosis-related pathways involved in SCI is affected after MSC transplantation. Accordingly, findings show that caspase-3-mediated apoptosis on neuron and oligodendrocyte cells following SCI is significantly downregulated by MSCs, which is regulated through stimulation of endogenous survival signaling pathways including PI3K/Akt, and the MAPK/ERK1/2-cascade..$^{50,51}$

Considering the contents mentioned above, it can be explained that mesenchymal cells are well suited for cell therapy of SCI. In this regard, many experiments in small and big SCI animal models have demonstrated the beneficial effects of MSCs from different sources. ${ }^{52,53}$ In addition, various studies are currently underway at various clinical stages using

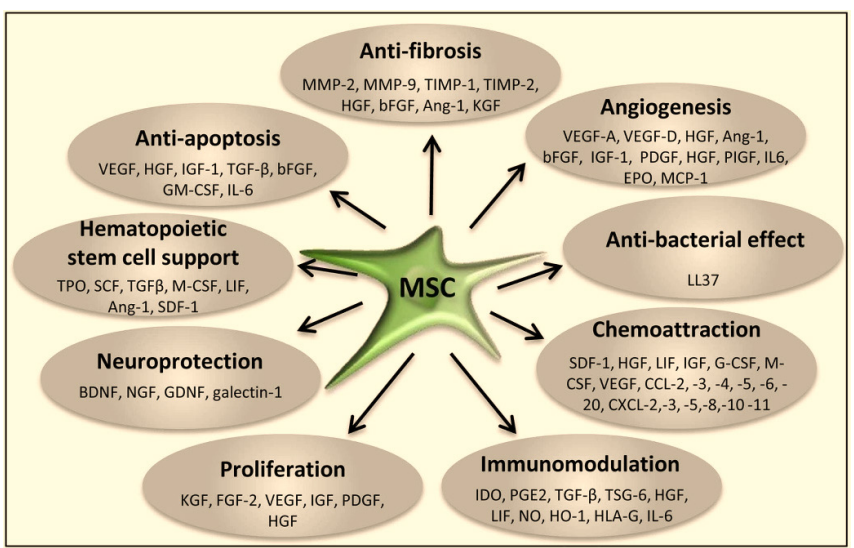

Figure 1. Different Effects of the Soluble Paracrine Factors Secreted by MSCs (https://anova-irm-stemcell-center.com).

MMP: Matrix metalloproteinase; TIMP: Tissue inhibitors of metalloproteinases; HGF: Hepatocyte growth factor; FGF: Fibroblast growth factor; Ang-1: Angiopoietin 1; KGF: Keratinocyte growth factor; VEGF: Vascular endothelial growth factor; IGF: Insulin-like growth factors; TGF: Transforming growth factor; GM-CSF: Granulocyte-macrophage colony-stimulating factor; TPO: Thrombopoietin; SCF: Stem cell factor; LIF: Leukemia inhibitory factor; SDF-1: Stromal cell-derived factor 1; BDNF: Brain-derived neurotrophic factor; NGF: Nerve growth factor; GDNF: Glial cell line-derived neurotrophic factor; PDGF: Platelet-derived growth factor; EPO: Erythropoietin; MCP-1: Monocyte chemoattractant protein-1; CCL: Chemokine (C-C motif) ligand; CXCL: Chemokine (C-X-C motif) ligand; IDO: Indoleamine 2, 3-dioxygenasase; PGE: Prostaglandin E2; TSG-6: TNF-stim ulated gene 6 protein; HO-1: Heme oxygenase-1; HLA-G: Human leukocyte antigen G; IL: interleukin. 


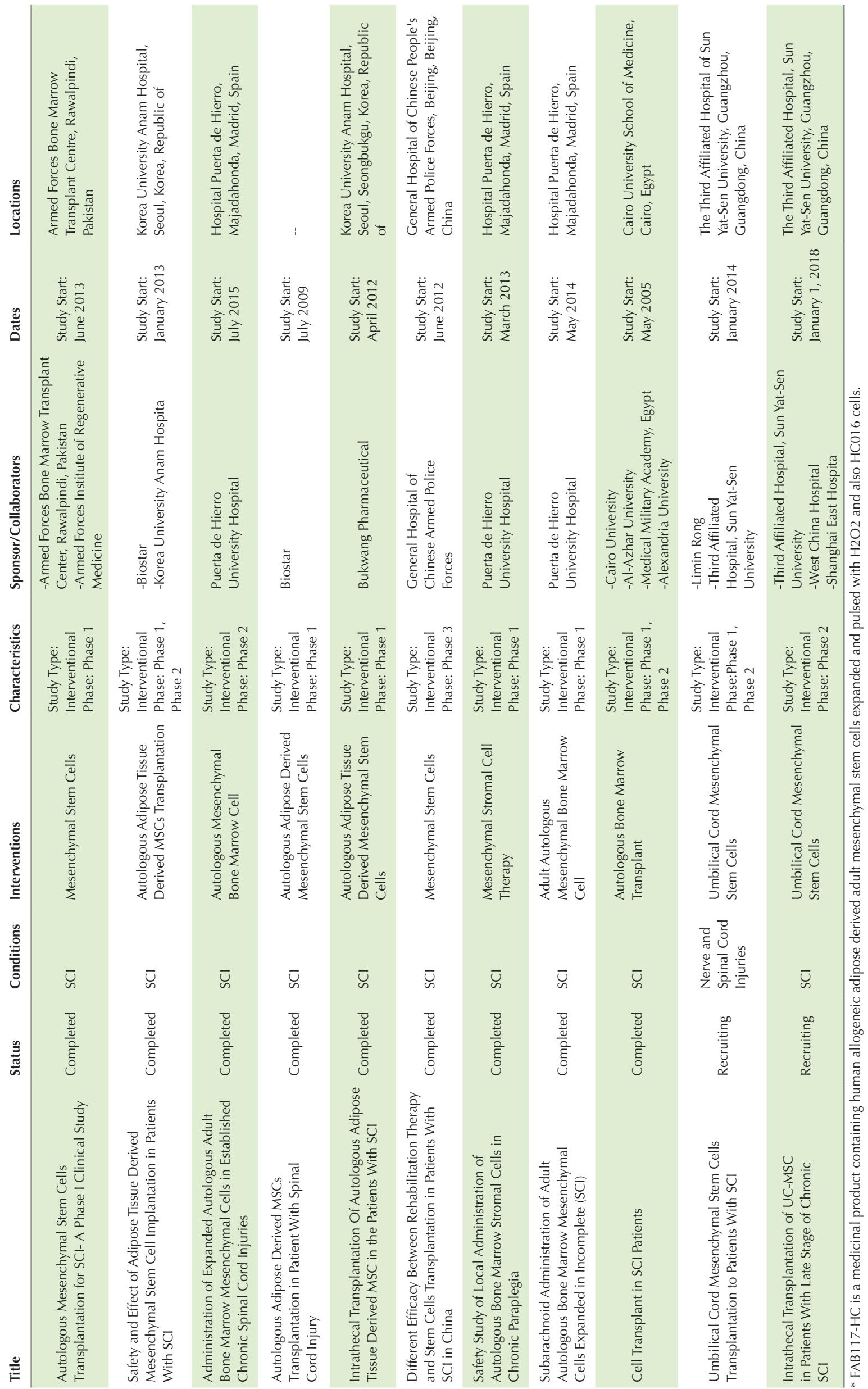


MSCs that their results are promising for the treatment of spinal cord injuries. Table 2 presents some clinical studies that have been performed using MCSs.

\section{Conclusions}

The main goals of stem cell-based therapies for SCI are the neuron replacement and restoration of neurological, structural, and functional of the spinal cord after injury. This type of therapy is regarded as promising methods because of their effectiveness in the treatment of SCI. However, determination of an effective and specific type of stem cell (due to the existence of different types of stem cells) for cell replacement therapy in patients, which can be used as a renewable source, is one of the key steps in this process. Moreover, some issues such as their effectiveness, ethical considerations and being as a safe option in such therapies is still a challenge and must be considered. However with regard to the potential of MSCs, it seems that these cells can be a significant option for the treatment of spinal cord injury using cell therapy.

\section{Authors' Contributions}

SF and AMS designed and directed the studies. MMM and SB contributed to the selection and organization of the article's contents. MMM wrote the manuscript with input from all authors. All authors have given approval to the final version of the manuscript.

\section{Conflict of Interest Disclosures}

The authors declare no competing financial interest.

\section{References}

1. Ahuja CS, Wilson JR, Nori S, et al. Traumatic spinal cord injury. Nat Rev Dis Primers. 2017;3:17018. doi:10.1038/nrdp.2017.18.

2. Hayta E, Elden H. Acute spinal cord injury: A review of pathophysiology and potential of non-steroidal anti-inflammatory drugs for pharmacological intervention. J Chem Neuroanat. 2018;87:25-31. doi:10.1016/j.jchemneu.2017.08.001.

3. Kang Y, Ding H, Zhou H, Wei ZJ, Liu L, Pan DY, et al. Epidemiology of worldwide spinal cord injury: a literature review. Journal of Neurorestoratology. 2018;6(1):1-9. doi:10.2147/JN.S143236.

4. The National SCI Statistical Center. Facts and Figures at a Glance. Birmingham, AL: University of Alabama at Birmingham; 2015:1-2.

5. Hagen EM. Acute complications of spinal cord injuries. World J Orthop. 2015;6(1):17-23. doi:10.5312/wjo.v6.i1.17.

6. Sezer N, Akkus S, Ugurlu FG. Chronic complications of spinal cord injury. World J Orthop. 2015;6(1):24-33. doi:10.5312/wjo. v6.i1.24.

7. Dorward N. Spinal Cord Medicine: Principles and Practice. London, England: SAGE Publications; 2003.

8. Dietz V, Fouad K. Restoration of sensorimotor functions after spinal cord injury. Brain. 2014;137(Pt 3):654-667. doi:10.1093/brain/ awt262.

9. Murray KC, Nakae A, Stephens MJ, et al. Recovery of motoneuron and locomotor function after spinal cord injury depends on constitutive activity in 5-HT2C receptors. Nat Med. 2010;16(6):694-700. doi:10.1038/nm.2160.

10. Sahni V, Kessler JA. Stem cell therapies for spinal cord injury. Nat Rev Neurol. 2010;6(7):363-372. doi:10.1038/nrneurol.2010.73.

11. Vismara I, Papa S, Rossi F, Forloni G, Veglianese P. Current options for cell therapy in spinal cord injury. Trends Mol Med. 2017;23(9):831-849. doi:10.1016/j.molmed.2017.07.005

12. Ross HH, Ambrosio F, Trumbower RD, Reier PJ, Behrman AL, Wolf SL. Neural stem cell therapy and rehabilitation in the central nervous system: emerging partnerships. Phys Ther. 2016;96(5):734742. doi:10.2522/ptj.20150063.

13. Jones LL, Oudega $M$, Bunge $M B$, Tuszynski MH. Neurotrophic factors, cellular bridges and gene therapy for spinal cord injury. J Physiol. 2001;533(Pt 1):83-89.

14. Lacroix S, Tuszynski MH. Neurotrophic factors and gene therapy in spinal cord injury. Neurorehabil Neural Repair. 2000;14(4):265275. doi:10.1177/154596830001400403.

15. Nadig RR. Stem cell therapy - Hype or hope? A review. J Conserv Dent. 2009;12(4):131-138. doi:10.4103/0972-0707.58329.

16. Chagastelles PC, Nardi NB. Biology of stem cells: an overview. Kidney Int Suppl (2011). 2011;1(3):63-67. doi:10.1038/ kisup.2011.15.

17. Thuret $\mathrm{S}$, Moon LD, Gage FH. Therapeutic interventions after spinal cord injury. Nat Rev Neurosci. 2006;7(8):628-643. doi:10.1038/ nrn1955.

18. Jiang L, Jones S, Jia X. Stem cell transplantation for peripheral nerve regeneration: current options and opportunities. Int J Mol Sci. 2017;18(1). doi:10.3390/ijms18010094.

19. Brustle $\mathrm{O}$, Jones $\mathrm{KN}$, Learish RD, et al. Embryonic stem cellderived glial precursors: a source of myelinating transplants. Science. 1999;285(5428):754-756.

20. Ramon-Cueto A, Cordero MI, Santos-Benito FF, Avila J. Functional recovery of paraplegic rats and motor axon regeneration in their spinal cords by olfactory ensheathing glia. Neuron. 2000;25(2):425-435.

21. Deshpande DM, Kim YS, Martinez T, et al. Recovery from paralysis in adult rats using embryonic stem cells. Ann Neurol. 2006;60(1):32-44. doi:10.1002/ana.20901.

22. Cloutier F, Siegenthaler MM, Nistor G, Keirstead HS. Transplantation of human embryonic stem cell-derived oligodendrocyte progenitors into rat spinal cord injuries does not cause harm. Regen Med. 2006;1(4):469-479. doi:10.2217/17460751.1.4.469.

23. Keirstead HS, Nistor G, Bernal G, et al. Human embryonic stem cellderived oligodendrocyte progenitor cell transplants remyelinate and restore locomotion after spinal cord injury. J Neurosci. 2005;25(19):4694-4705. doi:10.1523/jneurosci.0311-05.2005.

24. Cooney DS, Wimmers EG, Ibrahim Z, et al. Mesenchymal stem cells enhance nerve regeneration in a rat sciatic nerve repair and hindlimb transplant model. Sci Rep. 2016;6:31306. doi:10.1038/ srep31306.

25. Lee DC, Chen JH, Hsu TY, et al. Neural stem cells promote nerve regeneration through IL12-induced Schwann cell differentiation. Mol Cell Neurosci. 2017;79:1-11. doi:10.1016/j. mcn.2016.11.007.

26. Lavasani M, Thompson SD, Pollett JB, et al. Human muscle-derived stem/progenitor cells promote functional murine peripheral nerve regeneration. J Clin Invest. 2014;124(4):1745-1756. doi:10.1172/ jci44071.

27. Zhang SX, Huang F, Gates M, Holmberg EG. Role of endogenous Schwann cells in tissue repair after spinal cord injury. Neural Regen Res. 2013;8(2):177-185. doi:10.3969/j.issn.16735374.2013.02.011.

28. Kanno H, Pearse DD, Ozawa H, Itoi E, Bunge MB. Schwann cell transplantation for spinal cord injury repair: its significant therapeutic potential and prospectus. Rev Neurosci. 2015;26(2):121-128. doi:10.1515/revneuro-2014-0068.

29. Oudega M, Xu XM. Schwann cell transplantation for repair of the adult spinal cord. J Neurotrauma. 2006;23(3-4):453-467. doi:10.1089/neu.2006.23.453.

30. Kalra K, Tomar PC. Stem cell: basics, classification and applications. American Journal of Phytomedicine and Clinical Therapeutics. 2014;2(7):919-30.

31. Can A. A concise review on the classification and nomenclature of stem cells. Turk J Haematol. 2008;25(2):57-59.

32. Ulrich H. Stem cell reviews and reports: induced pluripotent stem cells, embryonic stem cells and development section. Stem Cell 
Rev. 2017;13(1):3. doi:10.1007/s12015-017-9722-8.

33. Yamanaka S. Induced pluripotent stem cells: past, present, and future. Cell Stem Cell. 2012;10(6):678-684. doi:10.1016/j. stem.2012.05.005.

34. Omole AE, Fakoya AOJ. Ten years of progress and promise of induced pluripotent stem cells: historical origins, characteristics, mechanisms, limitations, and potential applications. PeerJ. 2018;6:e4370. doi:10.7717/peerj.4370.

35. Yorukoglu AC, Kiter AE, Akkaya S, Satiroglu-Tufan NL, Tufan AC. A concise review on the use of mesenchymal stem cells in cell sheet-based tissue engineering with special emphasis on bone tissue regeneration. Stem Cells Int. 2017;2017:2374161. doi:10.1155/2017/2374161.

36. Mundra V, Gerling IC, Mahato RI. Mesenchymal stem cell-based therapy. Mol Pharm. 2013;10(1):77-89. doi:10.1021/mp3005148.

37. Zaminy A, Shokrgozar MA, Sadeghi Y, Norouzian M, Heidari MH, Piryaei A. Transplantation of Schwann cells differentiated from adipose stem cells improves functional recovery in rat spinal cord injury. Arch Iran Med. 2013;16(9):533-541. doi:013169/aim.0011.

38. Woodbury D, Schwarz EJ, Prockop DJ, Black IB. Adult rat and human bone marrow stromal cells differentiate into neurons. J Neurosci Res. 2000;61(4):364-370. doi:10.1002/10974547(20000815)61:4<364::aid-jnr2>3.0.co;2-c.

39. Shende P, Subedi M. Pathophysiology, mechanisms and applications of mesenchymal stem cells for the treatment of spinal cord injury. Biomed Pharmacother. 2017;91:693-706. doi:10.1016/j.biopha.2017.04.126.

40. Hasan A, Deeb G, Rahal R, et al. mesenchymal stem cells in the treatment of traumatic brain injury. Front Neurol. 2017;8:28. doi:10.3389/fneur.2017.00028.

41. Joyce N, Annett G, Wirthlin L, Olson S, Bauer G, Nolta JA. Mesenchymal stem cells for the treatment of neurodegenerative disease. Regen Med. 2010;5(6):933-946. doi:10.2217/rme.10.72.

42. QuJ,Zhang H. Roles of mesenchymal stem cells in spinal cord injury. StemCellsInt.2017;2017:5251313.doi:10.1155/2017/5251313.

43. Dasari VR, Veeravalli KK, Dinh DH. Mesenchymal stem cells in the treatment of spinal cord injuries: A review. World J Stem Cells. 2014;6(2):120-133. doi:10.4252/wjsc.v6.i2.120.

44. Dostert G, Mesure B, Menu P, Velot E. How Do Mesenchymal stem cells influence or are influenced by microenvironment through extracellular vesicles communication? Front Cell Dev Biol. 2017;5:6. doi:10.3389/fcell.2017.00006.

45. Jeong SR, Kwon MJ, Lee HG, et al. Hepatocyte growth factor reduces astrocytic scar formation and promotes axonal growth beyond glial scars after spinal cord injury. Exp Neurol. 2012;233(1):312-322. doi:10.1016/j.expneurol.2011.10.021.

46. Kitamura K, Fujiyoshi K, Yamane J, et al. Human hepatocyte growth factor promotes functional recovery in primates after spinal cord injury. PLoS One. 2011;6(11):e27706. doi:10.1371/journal. pone.0027706.

47. Urdzikova LM, Ruzicka J, LaBagnara M, et al. Human mesenchymal stem cells modulate inflammatory cytokines after spinal cord injury in rat. Int J Mol Sci. 2014;15(7):11275-11293. doi:10.3390/ ijms150711275.

48. Li L, Yang M, Wang C, et al. Effects of cytokines and chemokines on migration of mesenchymal stem cells following spinal cord injury. Neural Regen Res. 2012;7(14):1106-1112. doi:10.3969/j. issn.1673-5374.2012.14.010.

49. Ribeiro TB, Duarte AS, Longhini AL, et al. Neuroprotection and immunomodulation by xenografted human mesenchymal stem cells following spinal cord ventral root avulsion. Sci Rep. 2015;5:16167. doi:10.1038/srep16167.

50. Yin F, Guo L, Meng CY, et al. Transplantation of mesenchymal stem cells exerts anti-apoptotic effects in adult rats after spinal cord ischemia-reperfusion injury. Brain Res. 2014;1561:1-10. doi:10.1016/j.brainres.2014.02.047.

51. Isele NB, Lee HS, Landshamer $S$, et al. Bone marrow stromal cells mediate protection through stimulation of $\mathrm{PI} 3-\mathrm{K} / \mathrm{Akt}$ and MAPK signaling in neurons. Neurochem Int. 2007;50(1):243-250. doi:10.1016/j.neuint.2006.08.007.

52. Lee KH, Suh-Kim H, Choi JS, et al. Human mesenchymal stem cell transplantation promotes functional recovery following acute spinal cord injury in rats. Acta Neurobiol Exp (Wars). 2007;67(1):13-22.

53. Ramalho BDS, Almeida FM, Sales CM, de Lima S, Martinez AMB. Injection of bone marrow mesenchymal stem cells by intravenous or intraperitoneal routes is a viable alternative to spinal cord injury treatment in mice. Neural Regen Res. 2018;13(6):1046-1053. doi:10.4103/1673-5374.233448. 